\title{
CORPORATE GOVERNANCE IN EMERGING ECONOMIES
}

\author{
FRANKLIN ALLEN \\ University of Pennsylvania ${ }^{1}$
}

\begin{abstract}
Most of the literature on corporate governance emphasizes that firms should be run in the interests of shareholders. This is an appropriate objective function when markets are perfect and complete. In many emerging economies this is not the case: markets are imperfect and incomplete. The first theme of the paper is that alternative firm objective functions, such as pursuing the interests of all stakeholders, may help overcome market failures. The second theme is that it is not necessarily optimal to use the law to ensure good corporate governance. Other mechanisms such as competition, trust, and reputation may be preferable.
\end{abstract}

\section{INTRODUCTION}

In recent years interest in corporate governance has exploded. There are a number of reasons for this, but perhaps the most important is the corporate governance scandals that have occurred in the USA, Europe, and elsewhere. But what exactly is corporate governance? One common way of using the term is based on the following narrow definition.

Narrow view: Corporate governance is concerned with ensuring the firm is run in the interests of shareholders.

This is how the term is typically used in Anglo-Saxon countries such as the USA and UK. The standard mechanisms for ensuring that this occurs are: (i) the board of directors; (ii) executive compensation; (iii) the market for corporate control; (iv) concentrated holdings and monitoring by financial institutions; and (v) debt.

Underlying this narrow view of corporate governance is Adam Smith's notion of the invisible hand as the key principle that the organization of the economy is based on. The modern version of this idea is the Arrow-Debreu model and the fundamental theorems of welfare economics. The first theorem states that if the objective of firms is to maximize the wealth of their shareholders, and individuals pursue their own interests, then the allocation is Pareto efficient. The second theorem states that any Pareto-

${ }^{1}$ Prepared for the ECGI/Oxford Review of Economic Policy conference on Corporate Governance(Saïd Business School, Oxford, 28-29 January 2005). I am grateful to my discussant, George Dallas, and an anonymous referee for helpful comments and suggestions. 
efficient allocation can be implemented as a competitive equilibrium, given appropriate lump-sum taxes. In this view of the world the role of the firm in society is precisely to create wealth for shareholders and this is embodied in the legal framework. Many regard the law as playing an important role in corporate governance. In the USA and UK, managers have a fiduciary (i.e. very strong) duty to act in the interests of shareholders. This is why, in the legal literature, corporate governance is interpreted in the sense above. Pursuing shareholders' interests is what is required for the efficient use of resources. Issues concerning the equitable distribution of income are avoided by appeal to the second theorem of welfare economics. Desirable distributions can be ensured by appropriate redistribution through lump-sum taxes.

The Arrow-Debreu model is based on many strong assumptions. These include perfect and complete markets, symmetric information, perfect competition, and so forth. It ignores many realities of actual economies. If such realities are taken into account, then it is not clear that, even in developed economies, the firm's objective should be solely to pursue the interests of shareholders. In the context of emerging economies the assumptions of the Arrow-Debreu model are very suspect and the narrow view of corporate governance is not well founded. Despite this, much of the existing analysis of corporate governance in emerging economies takes it as given that this narrow view is the appropriate one. In addition, since the seminal contributions of La Porta, Lopez-de-Silanes, Shleifer, and Vishny $(1997,1998)$ (henceforth LLSV) and the many subsequent papers their work has stimulated, much of the focus of this literature is on ensuring that legal systems and institutions are such that the firm is run in the interest of shareholders. This existing literature is discussed in section II.

The first theme of this paper is that corporate governance should not necessarily be about ensuring the firm is run in the interests of shareholders. This approach is too narrow. When markets are imperfect and incomplete, as in many emerging economies, having an objective function for firms that is different from the narrow view may allow an improvement in the allocation of resources. Section III develops a view of corporate governance that is wider than that in the definition above. The alternative considered is the following.

Broad view: Corporate governance is concerned with ensuring that firms are run in such a way that society's resources are used efficiently.

This broad view encompasses the narrow view when markets are perfect and complete so the Arrow-Debreu assumptions are satisfied. In this case if firms pursue the interests of shareholders then the allocation of resources will be efficient. It is therefore sufficient to focus on the narrow view of corporate governance. With imperfect markets this broad objective can potentially make everybody better off compared to focusing on the shareholders' interests. For example, if there are externalities such as pollution, then maximizing the value of the firm is well known to cause a misallocation of resources. If firms were instead to use the broader view above, they would change their behaviour and produce the socially optimal level of pollution. In general, although it may not be possible to obtain efficiency, it may be possible to achieve a better allocation of resources with the broad view than with the narrow view.

In countries such as Japan, Germany, and France, it is this broad view that is often stressed. Rather than shareholders alone, a wider set of stakeholders, including employees and customers as well as shareholders, is considered. In fact, in Germany the legal system is quite explicit that firms do not have a sole duty to pursue the interests of shareholders. This is the system of codetermination. In large corporations employees have an equal number of seats on the supervisory board of the company, which is ultimately responsible for the strategic decisions of the company. In Japan, managers do not have a fiduciary responsibility to shareholders. The legal obligation of directors is such that they may be liable for gross negligence in performance of their duties, including the duty to supervise (Scott, 1998). In practice, it is widely accepted that they pursue the interests of a wide variety of stakeholders (see, for example, Allen and Gale, 2000a).

Section III discusses the broad view of corporate governance. It provides an example based loosely on Japan. It is shown that focusing on a wider group 
of stakeholders can lead to an allocation of resources that is Pareto better than when firms are run solely in the interests of shareholders. The different institutional structure leads to an allocation where the shareholders are, in fact, better off and so is everybody else. Moreover, it is argued that if the broad view of corporate governance is taken, then the interpretation of a number of empirical results that form the foundation for many current corporate governance policies can be quite different from the standard ones.

Section IV considers the second theme of the paper. This is that there are alternatives to the conventional wisdom that corporate governance policies in emerging economies should focus on providing an effective legal system and strong institutions. The first example considered is that of China. Allen et al. (2005) argue that China is a counterexample to the standard view that, to be successful, emerging economies should focus on establishing an effective legal system and institutions. China has a poor legal system in terms of design and enforcement and poor institutions. Nevertheless it has been very successful in economic terms for more than two decades. Mechanisms such as competition and reputation and trust appear to be at least as effective in ensuring an efficient allocation of resources as the standard corporate governance mechanisms stressed in the traditional literature.

The second example considered in section IV is that of the UK in the twentieth century. In an important contribution, Franks et al. (2003) have shown that a comparison of the first half of the twentieth century with the second half suggests that the law is not important in a number of respects in ensuring effective corporate governance in the narrow sense. Again, reputation and trust and other mechanisms appear to be quite effective.

Finally, section $\mathrm{V}$ considers the policy conclusions to be drawn from the analysis of the paper. The first is that a focus on whether firms are run in the interests of shareholders is too narrow. A broader view focusing on efficiency is preferable. The second policy implication is that ensuring that emerging economies have effective legal systems and institutions is neither necessary nor sufficient for ensuring good economic performance. Other mechanisms can be effective substitutes.

\section{THE CONVENTIONAL VIEW}

Claessens (2003) contains an excellent review of the literature on corporate governance and development and this section draws heavily on it. Most emerging economies are primarily interested in growth. The question is: what is the best way to achieve this?

LLSV and others have produced a substantial body of empirical evidence that links the origin of a country's legal system to the country's institutions and financial and economic 'outcomes', and in particular to economic growth. One of the central results of this literature is that countries with English common-law origin (French civil-law origin) provide the strongest (weakest) legal protection to both shareholders and creditors (LLSV, 1998, 2000). Countries with English-origin law also seem to have better institutions, including less corrupt governments (LLSV, 1999), more efficient courts (Djankov et al., 2003), and more informative accounting standards (LLSV, 1998). Better legal protection and better institutions, in turn, lead to better outcomes for the financial system, both at the aggregate and firm levels. For example, relative to firms in French-origin countries, firms in English-origin countries have more dispersed shareholder ownership (La Porta et al., 1999), rely more on external capital markets to raise funds (LLSV, 1997), have higher Tobin's Q (LLSV, 2002), and can enter a new market or industry more easily (Djankov et al., 2002).

Related to the LLSV results, there is a recent body of literature that attempts to understand why and how a country's legal origin affects the country's institutions, and how legal origin and institutions, both jointly and separately, affect economic and financial outcomes. Endeavours by researchers include examining the difference between contracting institutions and property rights institutions (e.g. Johnson et al., 2002; Acemoglu and Johnson, 2003); the endowment of geography and disease environment in former colonial countries (e.g. Acemoglu et al.,2001; Becketal.,2003a); the legal system's ability to adapt to evolving economic conditions (e.g. Posner, 1973; Beck et al., 2003b); and religion and cultural beliefs (e.g. Greif, 1994; Stulzand Williamson, 2003).

An important strand of this literature champions the view that the development of a financial system that 
includes a stock market and intermediation contributes to a country's overall economic growth (e.g. McKinnon, 1973). Recently, researchers have strengthened this view by presenting supporting empirical evidence at the country level (e.g. King and Levine, 1993; Levine and Zervos, 1998), as well as at the industry and firm levels (e.g. Jayaratne and Strahan, 1996; Rajan and Zingales, 1998). Also, there is evidence for a link between and causality among law, finance, and economic growth at the country, industry, and firm levels (e.g. DemirgüçKunt and Maksimovic, 1998; Levine, 1999; Beck and Levine, 2002).

What precise role does corporate governance play in the relationship between law, finance, and growth? Claessens (2003) argues that the first important factor is that better corporate governance leads to increased access to external financing. LLSV (1997) have shown that better creditor rights and shareholder rights are associated with more developed financial systems. Beck et al. (2002) have found that under conditions of poor corporate governance, fewer firms, and in particular fewer small firms, are set up. The second factor is concerned with firm valuation. Dyck and Zingales (2004) have found that the cost of capital is higher in countries with poor corporate governance. Claessens (2003) argues that there is a third factor which is the relationship between weak corporate governance and poor operational performance. However, this relationship is much weaker than that between corporate governance and access to external financing or that between corporate governance and the cost of capital. A fourth factor is the relationship between corporate governance and financial crises. Johnson et al. (2000) found that in the Asian financial crises weak investor protection was a key factor in exacerbating stock-market declines.

Given the narrow view of corporate governance, the policy implications based on this body of literature are clear. A good legal system leads to a good financial system and institutions, and this in turn leads to improved economic performance and, in particular, to growth. Hence, the key to fostering good economic outcomes and high growth is to establish a good legal system, including both the underlying laws and effective enforcement.

\section{A BROADER VIEW}

As discussed in the introduction, most of the literature on corporate governance has taken the narrow view that it is concerned with ensuring that firms are operated in the interests of shareholders. However, the theoretical justification for this view is based on perfect and complete markets and in many countries, particularly emerging ones, these assumptions are far from being satisfied. In this case a broader view of corporate governance that focuses on ensuring society's resources are used efficiently can be appropriate.

In many countries corporations do not appear to take creating wealth for shareholders as their main objective. For example, Table 1 contains a typical statement of corporate philosophy for a Japanese firm. It is this perspective on the role of the corporation in society that underlies the broad definition of corporate governance that is used.

The view that Japanese corporations have relatively little responsibility towards their shareholders is confirmed in surveys of managers. Figure 1 shows the choices of senior managers at a sample of major corporations in the five countries considered between the following two alternatives:

(a) a company exists for the interest of all stakeholders (dark bar);

(b) shareholder interest should be given the first priority (light bar).

In Japan the overwhelming response by 97 per cent of those asked was that all stakeholders were important. Only 3 per cent thought shareholders' interests should be put first. Germany and France are more like Japan in that 83 and 78 per cent, respectively, viewed the firm as being for all stakeholders. At the other end of the spectrum, managers in the USA and UK, by majorities of 76 and 71 per cent, respectively, stated that shareholders' interests should be given priority.

The same survey also asked the managers what their priorities were with regard to dividends and employee lay-offs. The specific alternatives they were asked to choose between were: 


\section{Table 1}

Corporate Philosophy of Asahi Breweries Ltd

We at Asahi Breweries, Ltd, through our business activities including alcoholic and nonalcoholic beverages, food and pharmaceuticals, wish to contribute to the health and well-being of people the world over. By thus contributing to society as a whole, the company seeks to attain the trust and confidence of the consumer and develop still further.

\section{Consumer Orientation}

Identifying the best interests of consumers, we endeavour to meet their demands by creating products suited for contemporary tastes and lifestyles.

\section{Quality First}

Open to consumer opinion of our products, we consistently enhance quality level and extend technological capabilities in order to market the finest products in the industry.

\section{Respect for Human Values}

Our Company firmly believes that human beings are the core of the business, and follows the principle of human values through developing human resources and implementing fair personnel management. Each employee is encouraged to fully utilize his or her own potential, and work to realize an open, positive thinking corporate culture.

4. True Partnership Between Labor and Management

Our Company aims to strengthen harmonious relations between labor and management based on mutual understanding and trust. Both parties work hand in hand for corporate development as well as the welfare of all employees.

\section{Cooperation with Business Associates}

We seek to build strong relations with all our business associates and affiliates in a spirit of co-existence and co-prosperity based in mutual trust. At the same time, we are determined to accept and fulfil our responsibilities as the core of the Asahi group of companies.

\section{Social Responsibilities}

We at Asahi, through securing and expanding the base of our operations, desire to fulfill our responsibilities to stockholders and the local communities in which we operate. Also in carrying out business activities, we sincerely observe the moral principles of management based on social standards.

Source: Asahi Breweries, Ltd. Case, 1989, Harvard Business School, 9-389-114.

(a) executives should maintain dividend payments, even if they must lay offa number of employees (dark bar);

(b) executives should maintain stable employment, even if they must reduce dividends (light bar).

Figure 2 shows the results. There is again a sharp difference between Japan, Germany, and France, and the USA and UK.

The evidence on managers' views of the role of the firm is upheld by the way that wages are structured in the different countries. In the USA and UK wages are based on the nature of the job done.
Employees' personal circumstances generally have no effect on their compensation. In Japan and Germany it is common for people to be granted family allowances and special allowances for small children. In France, vacation allowances based on family are common. These differences underline the fact that in the USA and UK the firm is designed to create wealth for shareholders, whereas in Japan, Germany, and France the firm is a group of people working together for their common benefit.

Although there has been an enormous amount of effort devoted to understanding the operation of Anglo-Saxon capitalism where firms pursue share- 


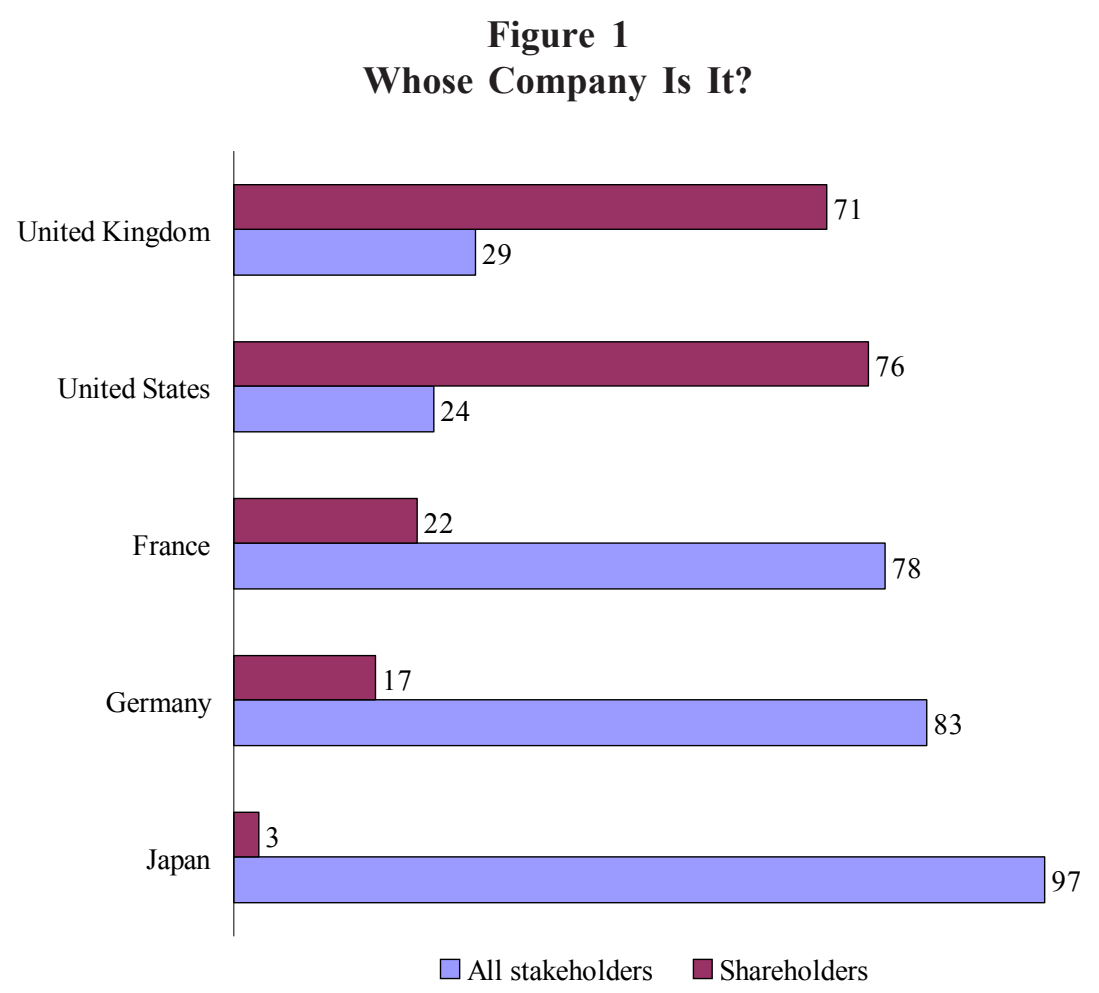

Notes: Number of firms surveyed: Japan, 68; United States, 82; United Kingdom, 78; Germany, 100; France, 50.

Source: Yoshimori (1995).

Figure 2

Job Security or Dividends?

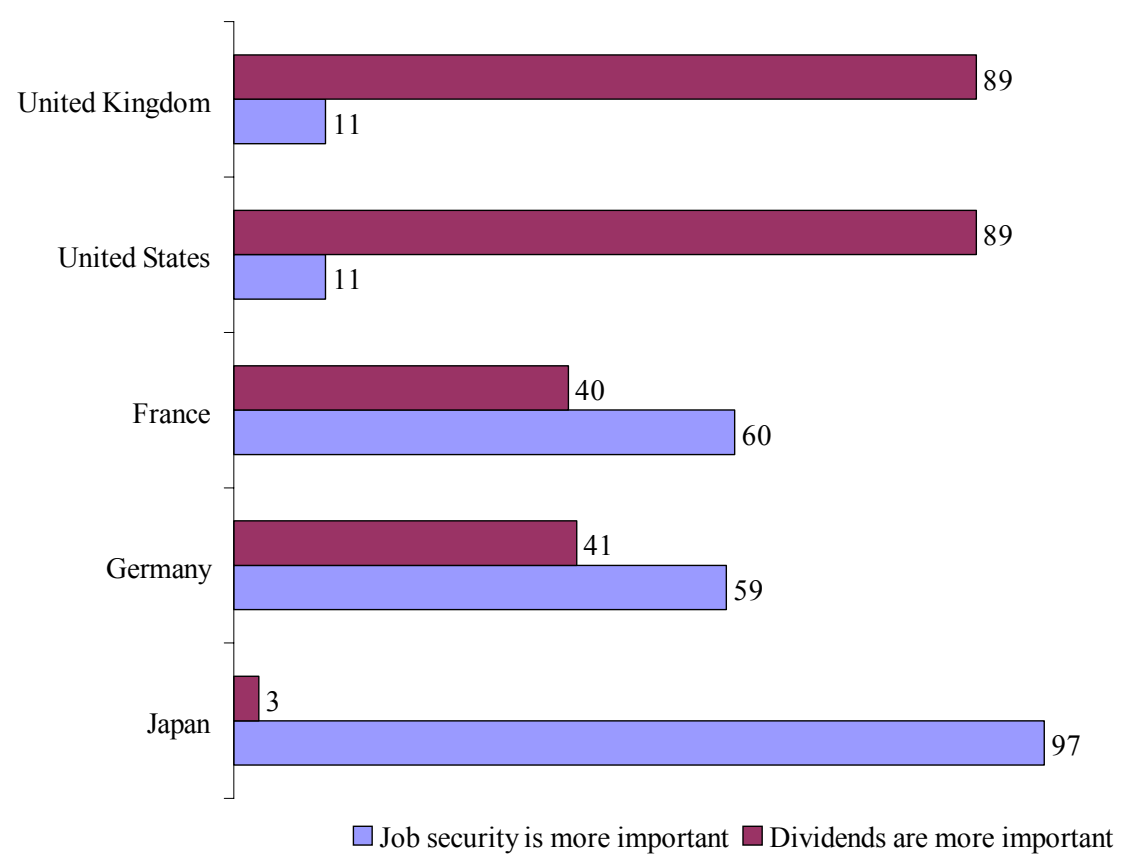

Notes: Number of firms surveyed: Japan, 68; United States, 83; United Kingdom, 75; Germany, 105; France 68.

Source: Yoshimori (1995). 
holders' interests, there has been relatively little devoted to stakeholder capitalism where firms pursue the interests of a variety of stakeholders.

The seminal work of Aoki and his co-authors is an example of the literature that looks at alternatives to Anglo-Saxon capitalism. In a sequence of contributions (see, for example, Aoki, 1984a, b, 1988, 1992) and edited volumes (Aoki, 1984c; Aoki et al., 1990; Aoki and Dore, 1994; Aoki and Patrick, 1994) great progress has been made in understanding the differences between Japanese and US firms. Aoki (1990) contains an excellent survey of this literature and exposition of some of the main ideas it contains. $\mathrm{He}$ contrasts the traditional US hierarchical firm, the 'H-mode', with the Japanese firm structure, the ' $\mathrm{J}$ mode'. The H-mode is characterized by (i) hierarchical separation between planning and implemental operation, and (ii) an emphasis on economies of specialization. The J-mode stresses (i) horizontal coordination among operating units based on (ii) the sharing of ex post on-site information. Aoki also develops the relationship in Japan between internal organization aspects of the firm and bank-oriented financial control, i.e. the main bank system. When a firm is in financial distress its main bank plays an important role in rescue operations. However, when a firm is financially sound its main bank does not become involved. In addition, the existence of crossholdings of shares among Japanese companies means there is no threat of hostile takeover. In the absence of outside control mechanisms, internal incentives are crucial. It is suggested that, among other things, 'lifetime employment', 'seniority advancement', and management discipline through competition over ranking by corporate profits are important. Also, the fact that management decisions of Japanese corporations are subject to the influence of employees as well as owners is stressed.

In this section, a model of the firm with overlapping generations (OLG) of employees based on the approach in Allen and Gale $(2000 a$, ch. 12) is developed. In this model, what happens when all the employees and managers of the firm must reach consensus and cooperate is considered. It is shown that this provides long-run incentives for the provision of effort. The necessity of this consensus and cooperation can lead to an efficient allocation of resources. By choosing strategies that attract young employees, the senior managers ensure that the long-run viability of the firms is maintained and all employees and the shareholders do well. The structure of these firms, where consensus is important and the interests of all stakeholders are pursued, is a simplified version of Aoki's J-mode firm. This stakeholder capitalism is contrasted with AngloSaxon capitalism, where firms are run by a single representative manager. This structure is a simplified version of Aoki's H-mode firm. In these firms a single representative manager makes all the decisions and it is not necessary to reach consensus. It is shown that this structure can be inferior to the Jmode both for employees and for shareholders.

\section{(i) A Cooperative Theory of the Firm}

In many countries the characterization of the firm as an institution exclusively concerned with maximizing some scalar measure of shareholder welfare would seem very strange. For example, the decision-making structure of the Japanese firm is different from that of the Anglo-Saxon corporation. In the USA and the UK, managers are given a large amount of freedom and are then monitored and disciplined by the market or by the corporate hierarchy if their performance is poor. Decision-making in Japan relies much more on consensus and the use of committees than on the entrepreneurial model favoured by the Anglo-Saxon corporation. The Japanese also make use of the seniority system: all managers have to pass through the ranks before they can achieve the top positions in the firm and CEOs spend relatively little time at the top compared to their American and British counterparts. There is also a much lower degree of inequality in compensation in the Japanese corporation. This is indicative of the importance of team work and the use of group performance to determine rewards in the Japanese firm.

The basic idea behind the analysis here is that different types of organization may lead to different behaviour. In particular, the role of consensus, teams, and hierarchy as they appear in the Japanese firm, among others, is emphasized. First, consider the time preferences that characterize different kinds of firms. As the debate on 'short-termism' in the USA has suggested, this may be a major and important difference between American and Japanese firms and one that may be traced to differences 
in organizational structure and culture. The next two subsections present a simple model of the firm's time preference and then subsequently apply these ideas to other aspects of the firm's behaviour.

\section{(ii) The Firm's Time Horizon}

To see the kind of issues that are involved, the focus is on one particular aspect of this problem, the time horizon implicit in the firm's decisions. Consider a firm where a single manager has all the power of decision-making. The idea that the manager is a rent-seeker, who pursues his own interests, is not necessarily antagonistic to the view that the firm is operated efficiently. For example, the manager's rents may happen to give him an income stream similar to that of a shareholder, in which case his incentive is to maximize the value of the firm (present value of net earnings). Of course, the incentives might be even better if he owned all of the shares, but having a part share may be much better than standard agency models, such as those investigated in Hart (1995), suggest.

There is, however, a problem with this view of the firm. The manager has only a temporary interest in the firm. More precisely, his interest in the firm is limited to his tenure in the job. Once he ceases to run the firm, the rents will flow to his successor. Even if he owns part of the firm, he can liquidate this holding on the day he leaves. As a result, a firm dominated by a single powerful manager may have a horizon which is no longer than the tenure of the manager.

An alternative type of organization is where a large corporation is run by a group of managers who, like the firm, may perpetuate itself more or less indefinitely. The interests of this group of managers, which is constantly renewing itself, will be quite different from that of any individual manager. The behaviour of an individual manager, depending as it does on expectations about how other members of the group will behave, will be quite different from the behaviour of a manager who controls all aspects of the firm's activities.

The difference between these two points of view, one of which identifies the behaviour of the firm with the decisions of a single manager, while the other regards the firm as being controlled by a sequence of overlapping generations of managers, can be illustrated by a simple example. Suppose that at any time two managers, one young and one old, are needed to run the firm. Each manager works for two periods and each period a new (young) manager is hired. The managers have two options. They can put effort into running the firm efficiently or they can engage in rent-seeking activities. Whatever they choose to do requires coordination. Unless they both cooperate in running the firm efficiently or, alternatively, both engage in rent seeking, the result will be worse for them than either of the alternatives just mentioned. The managers' rents depend on their allocation of effort. Let $r$ be the aggregate flow of pay-offs when both of the managers are making an effort to run the firm efficiently, and $R$ the rents when both are engaged in rent seeking. Naturally, it is assumed that $R>r>0$, where 0 is the managers' outside option. Suppose for simplicity that the payoffs and rents are divided evenly between the two managers, and that managers are risk neutral and do not discount the future. Then they will seek to maximize the sum of lifetime pay-offs and rents.

It is assumed that the only action the shareholders can take is to replace the managers if they observe rent-seeking behaviour. In practice, it will be difficult to replace managers and this will only be done with some delay, if at all. However, to make the point more strongly, let us assume that the shareholders are unusually powerful and can replace managers 'immediately' if they observe rent seeking. This means that the managers can achieve at most one period of high rents before they will be replaced. The question then is, under what conditions will the managers choose to engage in rentseeking behaviour?

Recall that coordination between the managers is required if they are to achieve any pay-offs of rents at all. One interpretation of this requirement is that if anyone deviates from an agreed plan the result is so disastrous that they all are worse off. Another interpretation is that the structure of decision-making in the firm requires consensus. Yet another interpretation is that managers are able to monitor each other and enforce an agreed-upon course of action. Whatever the interpretation, we will impose the requirement that the managers' actions will be 
changed only if everyone is willing to change. Thus, a given set of actions is an equilibrium unless everyone can be made better off by a deviation.

Suppose that the managers are pursuing the shareholders' interests. The pay-off to the young manager is $r / 2+r / 2=r$. The pay-off to the old manager is $r / 2$. If they were both to switch to rent seeking, the pay-off to the young manager would be $R / 2+0=R /$ 2 , since he would be replaced next period. The payoff to the old manager would be $R / 2$. Clearly, the old manager is better off, since $R>r$, but the young manager would be no better off if

$$
r \geq R / 2,
$$

which becomes the condition for viability of the policy of pursuing efficiency. The key point here is that the structure of the J-mode firm is such that the interests of all stakeholders are aligned.

As a benchmark, suppose that, instead of imposing this structure which requires consensus and the cooperation of all generations of management, it had been assumed that there existed a single, representative manager so that the firm has an H-mode structure. To maintain comparability across the two models, it is assumed that the choices available to the representative manager are the same and that the aggregate rents are the same. This means that the manager can either exert effort to run the firm efficiently or engage in rent seeking, that his perperiod payments in either case are $r$ and $R$ respectively, and that he is replaced after two periods on average. Suppose that he exerts effort for efficiency. When he is young, his pay-off from the given policy is $r+r=2 r$ and his pay-off from rent seeking is $R+0=R$, so the condition for him to continue pursuing the shareholders' interests is

$$
2 r \geq R,
$$

which is equivalent to the viability condition given above. In the second period, however, his pay-off from pursuing efficiency is only $r$, whereas the payoff from rent seeking is $R$. Since $R>r$, the policy of pursuing shareholders' interest is no longer viable. The H-mode can lead to a conflict between the interests of the managers and the shareholders in situations where with the J-mode firm all interests are aligned.
Allen and Gale $(2000 a$, 2003) show that this model can be extended in many different directions. The same argument extends immediately to a management structure involving $N$ managers, each of whom lives for $N$ periods. The lifetime pay-off to a manager who pursues efficiency is $r$, whereas the rents from deviating will only be $R / N$. The condition for viability in the J-mode firm becomes

$$
r \geq R / N,
$$

which becomes easier to satisfy as $N$ becomes large.

With a representative manager in the $\mathrm{H}$-mode firm who runs the firm for $N$ periods, the pay-off in the last period from rent seeking is $R$ and the pay-off from pursuing the shareholders' interests is $r$, so rent seeking will occur since

$$
R>r .
$$

Similarly, distinguishing the rents of managers of different ages makes no real difference to the argument.

The analysis above focused on different groups of managers. However, it can straightforwardly be seen that the analysis can be extended to include other stakeholders as well. For example, employees could also be included in the consultative process. If their cooperation is required, their interests will also be taken into account by the firm.

The simple representations of the J-mode and $\mathrm{H}$ mode above illustrate that the J-mode can be superior for all stakeholders. By requiring consensus and cooperation, the J-mode ensures that the firm will take a long-run perspective. This allows efficient decisions which are in the interest of all stakeholders to be made. In contrast with the $\mathrm{H}$-mode, managers nearing the end of their tenure can have an incentive to pursue their own interests rather than those of the firm as a whole.

It may be argued that the result concerning the superiority of the J-mode depends crucially on the shareholders being able to get rid of a lazy or selfserving management immediately, and that in reality managements are rather hard to replace. But a variant of the preceding story works even if it is 
impossible to replace the management. Provided that rent seeking by management will ultimately have bad effects on the firm and that the management structure is sufficiently far-sighted, the managers themselves will choose not to go down this road. The reason is that ultimately it will become impossible to motivate enough effort to keep the firm going, even in rent-seeking mode, and the anticipation of this event will cause the management coalition to unravel. As the discussion above suggests, an interesting interpretation of this model is the Japanese corporation. Managers pursue the longevity of the firm. As a by-product, shareholders do all right.

One of the important features of stakeholder capitalism is that employees cannot simply be fired at will. Lifetime employment and an inflexible labour market seem to be an important component of stakeholder capitalism. Allen and Gale (2003) show that these components of the economic system can improve the allocation of resources when firms have a J-mode structure. In order to be effective and induce the requisite effort from all employees there must be a sufficiently high probability of young workers remaining with the firm. An inflexible labour market helps provide incentives for cooperation. Allen and Gale (2003) also consider the issue of corporations' decisions when there is a downturn. It is shown that cutting dividends and maintaining wages and employment can be an optimal response of J-mode firms.

The Japanese company Toyota provides an interesting illustration of the idea that if companies pursue the interests of all stakeholders then a superior allocation of resources can be achieved. On 1 August 2001 the Financial Times reported details of the annual meeting of the International Corporate Governance Network which was held in Tokyo that year.

Hiroshi Okuda, chairman of Toyota Motor Corporation and of the Japan Federation of Employers' Associations, told the assembled money managers that it would be irresponsible to run Japanese companies primarily in the interests of shareholders. His manner of doing so left no doubt about the remaining depth of Japanese exceptionalism in corporate governance.

. . Mr Okuda made his point by telling guests what Japanese junior high school textbooks say about corpo- rate social responsibility. Under Japanese company law, they explain, shareholders are the owners of the corporation. But if corporations are run exclusively in the interests of shareholders, the business will be driven to pursue short-term profit at the expense of employment and spending on research and development.

To be sustainable, children are told, corporations must nurture relationships with stakeholders such as suppliers, employees and the local community. So whatever the legal position, the textbooks declare, the corporation does not belong to its owners.

No matter that all the research shows that stock markets respond favourably to higher research and development spending. Nor that the audience consisted chiefly of long-term investors, such as pension funds. The chasm between Japanese and Anglo-American views on what companies are for and whose interests they serve could not have been clearer. 'In Japan's case,' said Mr Okuda, 'it is not enough to serve shareholders.'

Despite this focus on all stakeholders, Toyota has done very well for its shareholders. Recently its market capitalization has been greater than that of General Motors, Ford, and DaimlerChrysler combined, despite the fact that the avowed aim of all these companies is to create wealth for shareholders.

Of course, not all Japanese firms have done as well as Toyota. Many have suffered sharp declines in their value since the busting of the Japanese bubble in the early 1990s. Consistent with the survey evidence quoted above, many firms have maintained employment at the expense of shareholders. Even though ex ante all stakeholders may be better off, ex post some may be worse off. This has important implications for how the results concerning studies of corporate governance should be interpreted. For example, as recounted in section II, during the Asian crisis the returns on the stock of firms with poor corporate governance in terms of the conventional view were worse than those of firms with better corporate governance. However, this may have been because other stakeholders were being treated better. A more efficient allocation of resources may require risk sharing between stakeholders, which results in poor ex post returns on stocks. Although this is a sign of poor corporate governance given the standard narrow view, it is consistent with superior corporate governance when the broader view is used. This underlines how important it is to focus on a wide set of indicators and 
not just stock returns to judge whether corporate governance is good or bad.

This section has mostly focused on Japan, which is clearly not an emerging economy. The reason is that it underlines most starkly the alternative broad view of corporate governance. The key question is whether, in emerging economies, the objectives of firms are more like those in the USA and UK or those in Japan, Germany, and France. Many might argue that they are much closer to the non-Englishspeaking countries. If this is the case a rather different approach is required to understanding corporate governance than the one that is usually followed.

\section{ALTERNATIVES TO THE LEGAL SYSTEM}

As discussed in the introduction, one of the themes of much of the literature on corporate governance is the importance of having an effective legal system. In this section, two examples where the legal system does not appear to have played an important role are discussed. The first is China.

Many of the studies in the law, finance, and growth literature, particularly the early ones, excluded China. Allen et al. (2005) have argued that China is an interesting counterexample. China is one of the most important countries in the world. At around 1.3 billion people, it has the largest population. Its GNP ranked sixth in the world as of 2002 in terms of US dollars. However, if purchasing power parity (PPP) is used to recalculate the GNPs, China's economy is the second largest behind only the USA as of 2002. The average annual growth rate of 11.3 per cent in PPP terms from 1990 to 2002 is much higher than the weighted average annual growth rates of the groups of countries studied by LLSV.

Using measures from the existing literature, Allen et al. (2005) find that China's legal system is significantly under-developed compared to the countries in the LLSV $(1997,1998)$ and Levine (2002) samples. Its corporate governance, accounting standards, and investor protection systems are poor at best, judging by existing standards in the literature, while its banking system is not well developed and is to a large degree inefficient. Its newly established
Shanghai Stock Exchange and ShenZhen Stock Exchange have been growing very fast since their foundation in 1990. While these stock exchanges have attracted a lot of attention from both investors and researchers, their scale and importance are still not comparable to other channels of financing, in particular the banking sector, for the entire economy.

How can the poor status of China's legal and financial systems, be reconciled with the spectacular success in growth since 1979, when China officially opened its door to the outside world? Allen et al.'s conclusion is that there exist very effective, non-standard mechanisms to support the financing and growth of the economy.

One of the most important mechanisms that drives good management and corporate governance is competition (see, for example, Nickell, 1996; Allen and Gale, 2000b). Competition appears a particularly important factor driving corporate governance in China. In many industries there is ferocious competition both from domestic and overseas firms.

A second very important factor is reputation and trust. Greif $(1989,1993)$ argues that certain traders' organizations in the eleventh century were able to overcome problems of asymmetric information and the lack of legal and contract enforcement mechanisms, because they had developed institutions based on reputation, implicit contractual relations, and coalitions. Certain aspects of the growth of these institutions resemble what works in China today. Gomes (2000) demonstrates that a managerial reputation effect can replace governance in an initial public offering (IPO) firm.

Another form of effective governance is family-run firms, as it has been shown that these firms emerge as the dominant form of ownership structure in countries with weak minority shareholder protections. Consistent with the findings in other Asian countries, many of China's successful private-sector firms have a very high fraction of the firm's stake owned by their founders and executives, and have performed very well. Finally, the success of the private sector would be impossible without the significant contribution from foreign investors, in particular investors from Hong Kong and Taiwan. In anticipating the possible loss of their investment owing to the failure of the firm, frauds, the almost 
non-existent formal investor protection rules, political risks, and, sometimes, prevalent corruption of local officials, why are they willing to finance and refinance these firms? An important reason is the common goal of sharing high prospective profits that ties local and foreign investors with entrepreneurs and managers to overcome numerous obstacles to achieve that goal. Under this common goal in a multi-period setting, implicit contractual agreements and reputation can act as enforcement mechanisms to ensure that each party fulfils its role to help the firm grow and generates profits. Profit sharing also makes it incentive compatible for officials at various levels not to disturb the operation of the firm.

The second example to illustrate that the legal system may be secondary compared to other factors, such as reputation and trust, is provided by the UK. Franks et al. (2003) point out that in the nineteenth century and first half of the twentieth century minority shareholders had very little legal protection. This did not prevent the development of large and successful securities markets, as the law and finance literature would suggest. In the middle of the twentieth century strong legal protections were introduced. The authors investigate the effect this had on the evolution of ownership of firms. They compare a sample of firms that were incorporated in 1900 with a sample that were incorporated in 1960. They find that the rate of equity issuance and the dispersion of ownership was roughly the same in both samples. In other words, the protection of minority shareholders did not affect these two factors at all. The authors argue that trust and reputation were responsible for this.

\section{POLICY CONCLUSIONS}

The first conclusion is that it is not always sufficient to focus on the issue of whether the legal framework and institutions ensure that firms are run in the interests of shareholders. When markets are perfect and complete this may be appropriate. But in many cases, particularly in emerging economies, this is not the case. Having a different objective function for the firm that, for example, focuses on all stakeholders rather than just shareholders, may lead to a superior allocation of resources than if the firm just focuses on the interests of shareholders. In addition to efficiency considerations, focusing on all stakeholders may have implications for inequality. In practice, lump-sum taxes are not used to redistribute income. If firms take account of all stakeholders this may result in a more equitable income distribution.

The second policy implication is that ensuring that emerging economies have effective legal systems and institutions is neither necessary nor sufficient for ensuring good economic performance. This raises the question of how finance for investment is obtained without investor protection and investororiented governance. Internal finance is one important mechanism. In China, for example, Allen et al. (2005) document that this is the most important source of funds for the private sector, where most of the country's growth has been generated. In many emerging countries the internal finance provided through conglomerates is particularly important.

Some might argue that effective legal systems and institutions cannot hurt, since alternative mechanisms such as competition and reputation and trust can work in the context of an effective legal system. Even this is not necessarily the case. If the legal system is effective but creates rents for some parties, then, as Rajan and Zingales (2003) have argued, there will be great resistance to change. Laws that are appropriate for one set of circumstances may remain in place long after these circumstances have changed. On the other hand, in systems which rely on reputation and trust but not the law, the barriers to change may be much lower since a few people may find it more difficult to block reform. The dynamic properties of systems that do not rely on the law may, therefore, be superior. 


\section{REFERENCES}

Acemoglu, D., and Johnson, S. (2003), 'Unbundling Institutions: Law vs. Politics', unpublished working paper, MIT.

- - Robinson, J. (2001), ‘The Colonial Origins of Comparative Development: An Empirical Investigation', American Economic Review, 91, 1369-401.

Allen, F., and Gale, D. (2000a), Comparing Financial Systems, Cambridge, MA, MIT Press.

- - - (2000b), 'Corporate Governance and Competition', in X. Vives (ed.), Corporate Governance: Theoretical and Empirical Perspectives, London, Cambridge University Press, 23-94.

_ _ _ (2003), 'A Comparative Theory of Corporate Governance', Wharton Financial Institutions Center, Working Paper 03-27, University of Pennsylvania.

- Qian, J., and Qian, M.(2005), 'Finance, Law, and Economic Growth in China', Journal of FinancialEconomics, forthcoming.

Aoki, M. (1984a), The Co-operative Game Theory of the Firm, Oxford, Oxford University Press.

- (1984b), 'Shareholders' Non-unanimity on Investment Financing: Banks vs. Individual Investors', in M. Aoki (ed.), The Economic Analysis of the Japanese Firm, Amsterdam, North-Holland.

- (ed.) (1984c), The Economic Analysis of the Japanese Firm, Amsterdam, North-Holland.

- (1988), Information, Incentives, and Bargaining in the Japanese Economy, New York, Cambridge University Press.

- (1990), 'Toward an Economic Model of the Japanese Firm', Journal of Economic Literature, 28, 1-27.

- (1992), 'Decentralization-Centralization in Japanese Organization: A Duality Principle', in S. Kumon and H. Rosovsky (eds), The Political Economy of Japan, Volume 3: Cultural and Social Dynamics, Stanford, CA, Stanford University Press, 142-69.

- Dore, R. (eds) 1994), The Japanese Firm: The Sources of Competitive Strength, Oxford and New York, Oxford University Press.

- Patrick, H. (eds) (1994), The Japanese Main Bank System: Its Relevancy for Developing and Transforming Economies, New York, Oxford University Press, 592-633.

- Gustafsson, B., and Williamson, O. (eds) (1990), The Firm as a Nexus of Treaties, London, Newbury Park, CA, Sage.

Beck, T., and Levine, R. (2002), 'Industry Growth and Capital Allocation: Does Having a Market- or Bank-based System Matter?', Journal of Financial Economics, 64, 147-80.

- Demirgüç-Kunt, A., and Levine, R.(2003a), 'Law, Endowments, and Finance', Journal of Financial Economics, 70, 137-81.

_ _ _ _ (2003b), 'Law and Finance: Why does Legal Origin Matter?', Journal of Comparative Economics, 31, 653-75.

- _Maksimovic, V.(2002), 'Financial and Legal Constraints to Firm Growth: Does Size Matter?', World Bank Working Paper 2784, Washington, DC.

Claessens, S. (2003), Corporate Governance and Development, in Focus 1: Corporate Governance and Development, Washington, DC, World Bank.

Demirgüç-Kunt, A., and Maksimovic, V.(1998), 'Law, Finance, and Firm Growth', Journal of Finance, 53,2107-37.

Djankov, S., La Porta, R., Lopez-de-Silanes, F., and Shleifer, A. (2002), 'The Regulation of Entry', Quarterly Journal of Economics, 117, 1-37.

_ _ _ _ (2003), 'Courts', Quarterly Journal of Economics, 118, 453-517.

Dyck, A., and Zingales, L. (2004), 'Private Benefits of Control: An International Comparison’, Journal of Finance, 59, 537-600.

Franks, J., Mayer, C., and Rossi, S. (2003), ‘Ownership: Evolution and Regulation’, unpublished working paper, London Business School.

Gomes, A. (2000), 'Going Public without Governance: Managerial Reputation Effects', Journal of Finance, 55, 61546.

Greif, A. (1989), 'Reputation and Coalitions in Medieval Trade: Evidence on the Maghribi Traders', Journal of Economic History, 49, 857-82.

- (1993), 'Contract Enforceability and Economic Institutions in Early Trade: The Maghribi Traders' Coalition', American Economic Review, 83, 525-48.

- (1994), 'Cultural Beliefs and the Organization of Society: A Historical and Theoretical Reflection on Collectivist and Individualist Societies', Journal of Political Economy, 102, 912-50.

Hart, O. (1995), Firms, Contracts and Financial Structure, Oxford, Clarendon Press. 
Jayaratne, J., and Strahan,P.(1996), 'TheFinance-Growth Nexus: Evidence from Bank Branch Deregulation', Quarterly Journal of Economics, 111, 639-70.

Johnson, S., McMillan, J., and Woodruff, C. (2002), 'Property Rights and Finance', American Economic Review, 92 , 1335-56.

- Boone, P., Breach, A., Friedman, E. (2000), 'Corporate Governance in the Asian Financial Crisis', Journal of Financial Economics, 58, 141-86.

King, R., and Levine, R. (1993), 'Finance and Growth: Schumpeter Might be Right', Quarterly Journal of Economics, 108, 717-38.

La Porta, R., Lopez-de-Silanes, F., and Shleifer, A.(1999), 'Corporate Ownership around the World', Journal of Finance, 54, 471-517.

- _ - - Vishny, R. (1997), 'Legal Determinants of External Finance', Journal of Finance, 52, 1131-50.

_ _ _ _ (1998), 'Law and Finance', Journal of Political Economy, 106, 1113-55.

_ _ _ _ (1999), 'The Quality of Government', Journal of Law, Economics, and Organization, 15, $222-79$.

_ _ _ _ _ (2000), 'Investor Protection and Corporate Governance', Journal of Financial Economics, 58, 14186.

_ _ _ _ (2002), 'Investor Protection and Corporate Valuation', Journal of Finance, 57, 1147-70.

Levine, R. (1999), 'Law, Finance, and Economic Growth', Journal of Financial Intermediation, 8, 36-67.

- (2002), 'Bank-based or Market-based Financial Systems: Which is Better?', Journal of Financial Intermediation, 11, 1-30.

- Zervos, S. (1998), 'Stock Market, Banks, and Economic Growth', American Economic Review, 88, 537-58.

McKinnon, R. (1973), Money and Capital in Economic Development, Brookings Institution Press.

Nickell, S. (1996), 'Competition and Corporate Performance', Journal of Political Economy, 104, 724-6.

Posner, R. (1973), Economic Analysis of the Law, Boston, MA, Little-Brown.

Rajan, R., and Zingales, L. (1998), 'Financial Dependence and Growth', American Economic Review, 88, 559-86.

- _ (2003), Saving Capitalism from the Capitalists, New York, Crown Business.

Scott, K. (1998), 'The Role ofCorporate Governance in South Korean Economic Reform', Journal of Applied Corporate Finance, 10, 8-15.

Stulz, R., and Williamson, R. (2003), 'Culture, Openness, and Finance', Journal of Financial Economics, 70, $261-300$. Yoshimori, M. (1995), 'Whose Company Is It? The Concept of the Corporation in Japan and the West', Long Range Planning, 28(4), 33-44. 